\title{
-Increased Serum Levels of IL-28, IL-29 and Protective Effect of IL28B rs8099917 Polymorphism in Patients with Hashimoto's Thyroiditis
}

\author{
-Dilek Arpaci ${ }^{1}$, Sevim Karakas Celik ${ }^{2}$, Murat Can ${ }^{3}$, Gunes Cakmak Genc ${ }^{4}$, Fatih Kuzu ${ }^{1}$, Mustafa Unal ${ }^{1}$, Taner Bayraktaroglu ${ }^{1}$ \\ -1 Bulent Ecevit University, Faculty of Medicine, Department of Endocrinology and Metabolism, Zonguldak, Turkey \\ - 2 Bulent Ecevit University, Faculty of Sciences and Arts, Department of Molecular Biology and Genetics, Zonguldak Turkey \\ -3 Bulent Ecevit University, Faculty of Medicine, Department of Biochemistry, Zonguldak, Turkey \\ -4 Bulent Ecevit University, Faculty of Medicine, Department of Genetics, Zonguldak, Turkey
}

\section{Background}

-Hashimoto's thyroiditis (HT) is thought to result from the decreased of $\mathrm{T}$ helper type 2 (Th2) responses, leading to progressive destruction of thyrocytes. IFN $-\lambda 1,-\lambda 2$, and $-\lambda 3$ (also known as IL-29, IL-28A, and IL-28B, respectively) is a recently described member of the IFN- $\lambda$ family and has been shown to decrease production of Th2 cytokines in vitro. However, the role and mechanism of IFN- $\lambda 1$ in Hashimoto's thyroiditis remain unknown

\section{Purpose}

- The purpose of our study is to elucidate whether the IL-29 and IL-28B gene polymorphisms are susceptibility genes for the development of HT. Also we aimed to investigate the effects of IL-29 and IL-28 serum levels on pathogenesis of HT.

\section{Material/Method}

Using the polymerase chain reactionrestriction fragment length polymorphism (PCR-RFLP) method, the single-nucleotide polymorphisms (SNPs) of IL28B rs8099917 (IL28 G/T) and IL29 rs30461 (IL29 T/C) were studied in 99 patients with HT and 100 healthy controls.

\section{Results}

Considering the allelic distribution for IL28 $\mathrm{G} / \mathrm{T}$ polymorphism a higher frequency of $\mathrm{G}$ allele was observed in the control group when compared to the HT group. So it was suggested that $G$ allele may be a protective role for HT pathogenesis $(\mathrm{OR}=0.38895 \%$-CI $0.217-0.693 ; \mathrm{p}=0.001)$.
Also our findings demonstrate that there was statistically significant difference in serum IL-28 and IL-29 levels between case and control groups $(\mathrm{p}<0.001)$. The increased serum levels of IL-28 and IL-29 in patients with HT was determined.

Table 1. The primer sequences, annealing Tm, restriction enzymes for detecting each single nucleotide polymorphism (SNP)

\begin{tabular}{|c|c|c|c|c|}
\hline SNP & $\begin{array}{l}\text { Reference } \\
\text { SNP ID }\end{array}$ & $\begin{array}{l}\text { Forward } \\
\text { primer } \\
\text { Reverse } \\
\text { primer }\end{array}$ & $\begin{array}{l}\text { Anneali } \\
\text { ng Tm }\end{array}$ & $\begin{array}{l}\text { Restriction } \\
\text { enzyme }\end{array}$ \\
\hline $\begin{array}{l}\text { IL28 } \\
\text { G/T }\end{array}$ & rs8099917 & $\begin{array}{l}\text { 5'- CAT CCC } \\
\text { TCA TCC } \\
\text { CAC TTC } \\
\text { TGG-3'(F) } \\
\text { 5'-CTG } \\
\text { GGC CAC } \\
\text { CAC AAT } \\
\text { TCA TC - } \\
\text { 3'(R) }\end{array}$ & $55^{\circ} \mathrm{C}$ & BsrDI \\
\hline $\begin{array}{l}\text { IL29 } \\
\text { T/C }\end{array}$ & rs30461 & $\begin{array}{l}\text { 5'- TGA ACA } \\
\text { TGC ACA } \\
\text { GTT ACG } \\
\text { CAC - 3'(F) } \\
5^{\prime} \text { - GAG CCA } \\
\text { ATA GGA } \\
\text { GCC CAG } \\
\text { AC - } \mathbf{3}^{\prime}(\mathbf{R})\end{array}$ & $54^{\circ} \mathrm{C}$ & AvaII \\
\hline
\end{tabular}

\section{Conclusion}

In conclusion, IL-28B gene polymorphism and serum IL-28 and IL-29 levels seemed to play a role in the pathogenesis of HT. 